\title{
Damages for reputational harm: can privacy actions tread on defamation's turf?
}

\author{
Jeevan Hariharan \\ Faculty of Laws, University College London
}

This article has been accepted for publication in the Journal of Media Law. A finalised version will appear in a forthcoming issue of the journal.

\begin{abstract}
In four recent cases, the High Court of England and Wales has had to consider whether damages for reputational harm can be recovered in a claim for misuse of private information ('MOPI'). This is an important issue which sharpens focus on the precise boundaries between privacy and defamation law. And yet it is a question on which the court is currently divided, with different judges coming to different conclusions on whether, and on what basis, reputational harm damages can be awarded in a privacy claim. This article argues that the key to resolving this issue is to better understand: (1) the precise interests protected by defamation and MOPI; and (2) how the interests protected by each tort are tied to the available heads of damage. Unpacking these points in turn, the article explains why damages for reputational harm should be restricted to defamation and be unavailable in a MOPI claim.
\end{abstract}

\section{Introduction}

If you successfully sue me in defamation, the main remedy a court will grant you is an award of "general damages". ${ }^{1}$ In cases of libel and slander actionable per se, where the law presumes damage arising from the defamatory publication, the principal

1 As the authors of the leading text Gatley on Libel and Slander point out, while it might be thought that the primary remedy for defamation would be corrective publication, such an order is rarely obtainable, so the main remedy is general damages. It has been repeatedly emphasised by courts that such damages are compensatory in nature, and serve three interconnected functions, which vary in emphasis from case to case: (1) to console you for the distress suffered from the publication of the defamatory statement; (2) to repair the harm to your reputation; and (3) as a vindication for your reputation. See Alastair Mullis and Richard Parkes (eds), Gatley on Libel and Slander (12th edn, Sweet \& Maxwell 2013) paras 9.1, 9.4. For a recent judicial statement of the relevant principles see Suttle $v$ Walker [2019] EWHC 396 (QB) [44], quoting from Barron v Vines [2016] EWHC 1226 (QB) [20]-[21] and John v MGN Ltd [1997] QB 586. 
function of these damages is to compensate for harm to your reputation. ${ }^{2}$ This is hardly surprising. After all, protecting a person's reputation is almost universally understood as the primary purpose of defamation law. ${ }^{3}$

But what if your reputation is injured by my actions or words, in circumstances where you have brought a claim other than defamation against me? Does defamation law have a monopoly on the legal protection of someone's reputation, such that damages for reputational harm are unavailable? Or should reputational harm be a potential basis for recovery in other causes of action as well?

Until recently, courts were confronted with the issue of damages for reputational harm outside defamation law relatively infrequently. ${ }^{4}$ This has changed significantly with the emergence of a dedicated privacy tort in English law in the last two decades. Although the issue has not garnered much detailed attention in commentary to date, ${ }^{5}$ there have been at least four recent misuse of private information ('MOPI') cases where the High Court has had to consider the availability of damages for reputational harm. ${ }^{6}$ As will be discussed in more detail below, the case law in this area is in a

2 James Edelman (ed), McGregor on Damages (21st edn, Sweet \& Maxwell 2021) para 46032.

3 See e.g. Lawrence McNamara, Reputation and Defamation (Oxford University Press 2007) 1; Mullis and Parkes (n 1) para 1.1. The precise interest that is protected by defamation law is discussed more extensively below.

4 If one goes back through the case books, references can be found to damages for injury to reputation being awarded for malicious falsehood (e.g. Savile v Roberts (1698) 1 Ld Raym 374, 91 ER 1147) and in certain false imprisonment cases (e.g. Walter $v$ Alltools Ltd (1944) 61 TLR 39). Such damages were also considered in detail in the context of a conspiracy action in Lonrho plc v Fayed (No 5) [1993] 1 WLR 1489 ('Lonrho'). This case is discussed in more detail below.

5 A number of articles have touched upon the issue, albeit without discussing the point extensively. See Jacob Rowbottom, 'Reporting Police Investigations, Privacy Rights and Social Stigma: Richard v BBC' (2018) 10 Journal of Media Law 115, 122-123; NA Moreham, 'Privacy, Reputation and Alleged Wrongdoing: Why Police Investigations Should Not Be Regarded as Private' (2019) 11 Journal of Media Law 142, 149-152; NA Moreham, 'Privacy and Police Investigations: ZXC v Bloomberg' (2021) 80 The Cambridge Law Journal 5, 6-7; David Rolph, 'Reputation beyond Defamation' (Inforrm's Blog, 13 August 2018) <https://inforrm.org/2018/08/13/reputation-beyond-defamationdavid-rolph/> accessed 2 June 2021. Overall, however, the issue remains largely underanalysed. In the latest edition of McGregor on Damages, for instance, there is a chapter devoted to damages in privacy cases, but only very brief mention of damages for reputational harm: Edelman (n 2) ch 47.

6 Hannon v News Group Newspapers Ltd [2014] EWHC 1580 (Ch), [2015] EMLR 1 ('Hannon'); Richard v BBC [2018] EWHC 1837 (Ch), [2019] Ch 169 ('Richard'); ZXC v 
confusing state, with different judges adopting different positions on whether, and on what basis, reputational harm damages can be awarded in privacy claims.

In addition to being a live question, the issue of reputational harm damages has broader significance because it sharpens focus on the precise boundaries between privacy and defamation law, and how the two areas interact in practice. ${ }^{7}$ If such damages are available in privacy cases, the dividing line between privacy and defamation law becomes more difficult to determine. ${ }^{8}$ In particular, there is a risk of privacy actions expanding in scope and being wielded to circumvent the strict rules and defences which have been crafted over time in defamation law to strike an appropriate balance with freedom of expression. ${ }^{9}$

This article argues that damages for injury to reputation should not be available in privacy claims. This is not because invading a person's privacy might not residually have an impact on their reputation. Rather, it is because damages for reputational harm are a very particular species of damages, which I call 'interference damages', awarded by courts for interference with the 'core' interest protected by a tort. For the tort of defamation, the core interest protected is a person's reputation, but not reputation in the general sense of others thinking well of the person. Rather, defamation protects an individual's specific interest in not having their standing in society besmirched by false allegations.

The MOPI tort, by contrast, chiefly protects a person's interest in their informational privacy. In certain situations, it is true that keeping information about oneself private will help to keep one's reputation intact. However, the incidental sense in which reputation is protected by privacy actions is very different to the specific reputational interest protected by defamation law. To the extent that one's reputation is harmed as a result of a privacy invasion, such impacts should not be compensable in a MOPI action by an award of reputational harm damages. MOPI already has its own form of

Bloomberg LP [2019] EWHC 970 (QB), [2019] EMLR 20 ('ZXC'); Sicri v Associated Newspapers Ltd [2020] EWHC 3541 (QB), [2021] 4 WLR 9 ('Sicri'). See also Hayden v Duckworth [2021] EWHC 1033 (QB) [28].

7 It should, however, be noted that this article is limited to the issue of whether reputational harm damages are available where MOPI has been successfully established. As such, the paper does not discuss in any length the issue of whether, or in what circumstances, it is an abuse of process to bring a privacy claim in order to circumvent the rules of defamation or avoid the rule in Bonnard v Perryman [1891] 2 Ch 269 at the interlocutory stage (as discussed e.g. in McKennitt v Ash [2006] EWCA Civ 1714, [2008] QB 73 [79] (Buxton LJ)) ('McKennitt').

8 See Rolph (n 5).

9 Rowbottom (n 5) 122. 
interference damages which are awarded for interference with the core interest the tort protects, i.e. damages for 'loss of control of information'.

The rest of the article proceeds in four sections. The first section outlines two important features about the MOPI action which are necessary context for the rest of the discussion. These relate to current jurisprudence on the privacy of police investigations and how courts approach damages in MOPI claims. The second section then explores how courts have reasoned when considering reputational harm damages in privacy claims thus far. The tension in these decisions, it is argued, arises because there is a lack of clarity as to: (1) the precise interests protected by defamation and privacy actions; and (2) how the interests protected by each tort interact with the available heads of damage when the elements of the tort are satisfied. The third and fourth sections of the article delve deeper into each of these points in turn, substantiating the claim that reputational harm damages and loss of control damages are best understood as interference damages, which are tethered to defamation and privacy claims respectively.

\section{Current MOPI jurisprudence: two background issues regarding the right and its remedies}

The MOPI action has been with us for almost twenty years now, so is at an interesting point in its development. The foundational matters are no longer in doubt. It is now firmly established that MOPI is a standalone tort, ${ }^{10}$ available where: (1) the claimant has a reasonable expectation of privacy in the relevant information; and (2) that expectation is not outweighed by a countervailing interest, most commonly the defendant's right to freedom of expression. ${ }^{11}$ Moreover, while the circumstances in which courts will find a reasonable expectation of privacy is continually being refined, it has been clear for some time now that there is certain material regarded as

10 Vidal-Hall v Google Inc [2015] EWCA Civ 311, [2016] QB 1003.

11 This is the way the test is articulated by the Court of Appeal in the latest MOPI case at the time of writing, ZXC v Bloomberg LP [2020] EWCA Civ 611, [2021] QB 28 [42] ('ZXC $\left.C A^{\prime}\right)$. 
paradigmatically private. ${ }^{12}$ This includes information related to one's health, ${ }^{13}$ sexual life,${ }^{14}$ family life,${ }^{15}$ and the details of one's personal relationships. ${ }^{16}$

However, in addition to these points which are now relatively uncontroversial, there are further aspects of the action which have only recently been clarified, and will likely be the subject of continued judicial development. Two such points are particularly significant for the current discussion about reputational harm damages.

The first is that over the last few years, there has been growing judicial support for the proposition that a person generally has a reasonable expectation of privacy in a police investigation concerning them. ${ }^{17}$ In ZXC v Bloomberg, the most recent Court of Appeal decision on the issue, Simon LJ concisely summarised the current legal position on this issue and its rationale as follows:

[T] hose who have simply come under suspicion by an organ of the state have, in general, a reasonable and objectively founded expectation of privacy in relation to that fact and an expressed basis for that suspicion. The suspicion may ultimately be shown to be well founded or ill-founded, but until that point the law should recognise the human characteristic to assume the worst (that there is no smoke without fire);

12 NA Moreham, 'Unpacking the Reasonable Expectation of Privacy Test' (2018) 134 Law Quarterly Review 651, 659-660.

13 E.g. Campbell v MGN Ltd [2004] UKHL 22, [2004] AC 457 [53] (Lord Hoffmann), [145] (Baroness Hale) ('Campbell'); McKennitt (n 7) [23] (Buxton LJ).

14 E.g. PJS v News Group Newspapers Ltd [2016] UKSC 26, [2016] AC 1081 [32] (Lord Mance); Mosley v News Group Newspapers Ltd [2008] EWHC 1777 (QB), [2008] EMLR 20 [98]-[100].

15 E.g. Murray v Express Newspapers plc [2008] EWCA Civ 446, [2009] Ch 481 [55]; A Local Authority v A Mother [2011] EWHC 1764 (Fam), [2012] 1 FLR 239 [64].

16 E.g. Gulati v MGN Ltd [2015] EWHC 1482 (Ch), [2016] FSR 12 [229(iv)].

17 ZXC (n 6) [119] citing, inter alia, Hannon (n 6); ERY v Associated Newspapers Ltd [2016] EWHC 2760 (QB), [2017] EMLR 9; Richard (n 6). Some prominent commentators, such as Nicole Moreham, have criticised this body of case law, arguing that information regarding police investigations should not generally be regarded as private. Instead, according to Moreham, breach of confidence might be a better avenue for liability in certain limited circumstances: Moreham, 'Privacy, Reputation and Alleged Wrongdoing' (n 5); NA Moreham, 'Police Investigations, Privacy and the Marcel Principle in Breach of Confidence' (2020) 12 Journal of Media Law 1. Persuasive as these arguments may be, this paper will not discuss whether police investigations are the proper subject of a MOPI action. The article is limited to the issue of whether reputational harm damages should be available in MOPI cases. 
and to overlook the fundamental legal principle that those who are accused of an offence are deemed to be innocent until they are proven guilty. ${ }^{18}$

The development of privacy law around criminal investigations has been crucial in bringing to the fore cases where individuals are claiming that they should be compensated for the reputational harm consequential upon an invasion of privacy. Details of police investigations are, of course, not the only type of information which someone will want to keep private and will have a considerable reputational impact if released. One can imagine people wanting, for example, to keep their disease history or sexual proclivities to themselves precisely because there will be a negative impact on their reputation if that information gets out. As it happens, however, every MOPI case to date where reputational harm damages have been considered in any detail seems to have involved the privacy of police investigations. ${ }^{19}$

The second point concerns damages in successful MOPI claims. As a standalone tort, it is not in dispute that the chief purpose of MOPI damages is to compensate the claimant for the losses they incur as a result of the privacy invasion. ${ }^{20}$ In most cases, the sum awarded is mainly for the 'distress' suffered by the claimant, which is a recognised head of non-pecuniary loss in tort law. ${ }^{21}$ If the claimant has had any pecuniary losses flowing from the privacy invasion, these are in principle recoverable as well. ${ }^{22}$ Recently, however, and crucially for current purposes, it has been recognised that claimants can additionally be entitled to a sum of damages compensating for the 'loss of control of information' which occurs in an invasion of privacy. These damages were recognised for the first time in Gulativ MGN, a case involving the phone hacking of various claimants by the Daily Mirror and other newspapers. Mann J reasoned as follows:

If one has lost 'the right to control the dissemination of information about one's private life' then I fail to see why that, of itself, should not attract a degree of

18 ZXC CA (n 11) [82]. At the time of writing, this decision is pending an appeal to the Supreme Court. This appeal is addressed in the final section of this article.

19 These cases are discussed in the next section of the article.

20 See Sicri (n 6) [138].

21 Edelman (n 2) paras 5-013, 47-002.

22 ibid 47-016; Eric Descheemaeker, 'The Harms of Privacy' (2015) 7 Journal of Media Law 278, 281. Claims for pecuniary losses in privacy cases are relatively rare. But they have come up in some recent cases. For example, in Richard (n 6) [370]-[430], Mann J found that various pecuniary losses were caused by the BBC's violation of Richard's privacy rights including legal costs associated with removing a hostile Facebook group and a lost book advance. 
compensation, in an appropriate case. A right has been infringed, and loss of a kind recognised by the court as wrongful has been caused. ${ }^{23}$

On appeal, Mann J's judgment was affirmed in substantially the same terms. Arden LJ (with whom Rafferty and Kitchen LJJ agreed) said on this point:

In my judgment, the judge was correct to conclude that the power of the court to grant general damages was not limited to distress and could be exercised to compensate the claimants also for the misuse of their private information. The essential principle is that, by misusing their private information, MGN deprived the claimants of their right to control the use of private information. ${ }^{24}$

Awarding damages for loss of control of information, or 'loss of control damages' as they are sometimes called, is a controversial matter. While some authors, such as Jason Varuhas ${ }^{25}$ and Nicole Moreham ${ }^{26}$ have defended awards of substantial damages in MOPI cases regardless of whether the claimant has suffered distress or pecuniary losses, others including Eric Descheemaeker ${ }^{27}$ contend that the current approach is conceptually incoherent. What is important for present purposes is simply that such damages have been judicially accepted and are now being awarded in most successful MOPI claims in addition to damages for distress. ${ }^{28}$ While the precise significance of loss of control damages will only be apparent once the discussion in the final section of this article is complete, it is important to take note of the exact way courts are framing such awards. Loss of control damages, as explained by Mann $\mathrm{J}$ and Arden LJ in the above passages, compensate claimants for the loss of control over the use of

23 Gulati v MGN Ltd (n 16) [111] (emphasis added).

24 Gulati v MGN Ltd [2015] EWCA Civ 1291, [2017] QB 149 [45].

25 Jason NE Varuhas, 'Varieties of Damages for Breach of Privacy' in Jason NE Varuhas and NA Moreham (eds), Remedies for Breach of Privacy (Hart Publishing 2018).

26 NA Moreham, 'Compensating for Loss of Dignity and Autonomy' in Jason NE Varuhas and NA Moreham (eds), Remedies for Breach of Privacy (Hart Publishing 2018).

27 Descheemaeker, 'The Harms of Privacy' (n 22); Eric Descheemaeker, 'Claimant-Focused Damages in the Law of Privacy' in Jason NE Varuhas and NA Moreham (eds), Remedies for Breach of Privacy (Hart Publishing 2018).

28 See Richard (n 6) [350](a); ZXC (n 6) [147]; Sicri (n 6) [138](2). In the Supreme Court's recent decision in Lloyd v Google LLC [2021] UKSC 50 ('Lloyd'), which considered the availability of damages for loss of control of information under the Data Protection Act (1998) ('DPA'), the correctness of the Gulati approach was not challenged by either party. Lord Leggatt (with whom the other Justices agreed) firmly rejected the submission that loss of control damages are recoverable under the DPA. However, his judgment proceeds on the basis that such damages are available in the MOPI context: see [100]-[106], [133][135]. 
their private information. Thus, in appropriate cases, the infringement of the right which MOPI protects is, by itself, attracting an award of substantial damages.

\section{The differing approaches to reputational harm damages in MOPI cases}

Armed with these details about the MOPI action, we can turn now to examining the specific cases where damages for reputational harm have been dealt with. There are four High Court cases in which this issue has arisen for detailed consideration: Hannon v News Group Newspapers, Richard v BBC, ZXC v Bloomberg, and Sicri v Associated Newspapers. ${ }^{29}$ Each of these cases, as alluded to above, is one where the claimant was seeking legal redress for the release of information about them pertaining to a police investigation.

\section{How the reputational harm issue arose in each case}

In Richard, ZXC, and Sicri, the court found that the claimant had successfully established a MOPI claim because the defendant journalist had publicised details of a police investigation into the claimant's alleged criminal activity. The misconduct being investigated which was publicised in each case was serious. In Richard, the BBC had reported that Sir Cliff Richard was being investigated for historical sexual abuse and that his property was being searched as a part of that investigation. ${ }^{30} \mathrm{In}$ $Z X C$, Bloomberg published an article based on a highly confidential letter of request sent by a UK law enforcement body to a foreign government requesting assistance with an investigation into possible offences of corruption and bribery involving the claimant. ${ }^{31}$ And in Sicri, the Daily Mail's website MailOnline published articles reporting on the arrest of the claimant who was being investigated on suspicion of terrorist offences following the 2017 Manchester Arena bombings ${ }^{32}$ In all three cases,

29 Reputational harm damages have also come up at least once when determining compensation under data protection legislation: see Aven v Orbis Business Intelligence Ltd [2020] EWHC 1812 (QB) ('Aven'). In Aven, the issue did not require detailed consideration because the defendant conceded that, in principle, compensation for reputational harm could be awarded under the DPA, s 13 (see at [196]). This article focuses on MOPI, so data protection legislation is not considered further. Separating MOPI and data protection damages in this way is consistent with Lloyd (n 28). There, the Supreme Court emphatically rejected the argument that the approach taken to MOPI damages could be adopted by analogy in the DPA context: [105]-[135]. I come back to Lloyd briefly in the last section of the article.

30 Richard (n 6) [115]-[143].

31 ZXC (n 6) [8]-[18].

32 Sicri (n 6) [1]-[5]. 
the court had to consider whether the sum awarded to the claimant could include an amount for the reputational harm caused by the wrongful publication, or whether compensation was limited to distress, loss of control damages, damage to health and any pecuniary losses. ${ }^{33}$

Hannon is a slightly different decision because the issue of reputational harm damages arose in the context of a strike-out application, rather than after a finding of liability. That case involved two claims on different facts, both involving sensationalist articles in the Sun which were based on information journalists had obtained by paying the police. ${ }^{34}$ In the first claim, the Sun had published an article detailing the arrest and detention of an Air Canada pilot who was removed from a flight prior to take off and taken for blood tests following a positive breathalyser test. ${ }^{35}$ In the second, the Sun published a story reporting that the claimant, a model, 'went mad' during a flight when she discovered that her boyfriend had behaved inappropriately with another passenger, and that all three of them had been arrested at the end of the flight. ${ }^{36}$ The newspaper sought to strike out both claims as being an abuse of process. It argued that the 'nub' of the claims was to protect the right to reputation and therefore that the actions should have been brought in defamation, not privacy. ${ }^{37}$

\section{Reputational harm damages can be awarded in MOPI claims: Hannon and Richard}

Hannon and Richard were judgments delivered by Mann J. In both cases, he decided that damages for reputational harm were not the sole province of defamation law, and could be available in a MOPI claim as well. That meant reputational injury was a component of the $£ 210,000$ in general and aggravated damages which was awarded to Richard. And in Hannon, the defendant was unsuccessful in striking out the claims. While the issue was expressed slightly differently in these cases, there are two broad points which seem fundamental to Mann J's conclusion. The first point is a negative claim that pre-MOPI cases dealing with reputational injury outside of defamation law are not applicable in the MOPI context. The second point is a positive claim that part

33 Note, $Z X C$ was subject to appeal, but damages were not at issue, nor were they considered by the Court of Appeal: see ZXC CA (n 11) [143] (Simon LJ), [151] (Underhill LJ). As noted above at footnote 18, the Court of Appeal's decision is now subject a further appeal to the Supreme Court which is currently pending.

34 Hannon (n 6) [1]-[3].

35 ibid [6]-[7].

36 ibid [12]-[13].

37 ibid [16]-[19]. See also Eric Barendt, ‘An Overlap of Defamation and Privacy?' (2015) 7 Journal of Media Law 85. 
of the function of English privacy law is to protect reputation, and that this needs to be reflected when the court awards damages. It is worth unpacking each point in turn.

On the first point, the main case which Mann J distinguished was Lonrho v Fayed (No 5), a 1993 Court of Appeal decision which the defendants in both Richard and Hannon relied on for the proposition that reputational harm damages were unrecoverable in MOPI. Lonrho concerned the tort of conspiracy, and was decided well before the modern MOPI action was developed. Importantly, however, the Court of Appeal had unanimously held that, as a general rule, damages for injury to reputation could only be recovered in a defamation action. According to Dillon LJ, 'Injury to reputation and to feelings is, with very limited exceptions, a field of its own and the established principles in that field are not to be side-stepped by alleging a different cause of action'. ${ }^{38}$ In particular, he pointed out that truth was an absolute defence to a defamation action, and that allowing reputational harm to be compensable in a conspiracy action would have the 'lamentable' consequence that telling the truth would be wrongful. ${ }^{39}$ Stuart Smith LJ similarly held that the principled reason why an individual must sue for injury to reputation in defamation is that 'no one has a right to reputation which is unmerited' ${ }^{40}$ Defamation law gives proper effect to this principle because truth is a complete defence.

According to Mann J, it was not appropriate to carry across the reasoning from Lonrho to the MOPI context. Discussing the issue in Hannon ${ }^{41}$ (and referring back to these remarks in Richard ${ }^{42}$ ), Mann J said that the important claim underpinning Lonrho was that if reputational harm damages were awarded in a conspiracy action, telling the truth would be rendered wrongful. That logic, for Mann J, was not transferable to the MOPI context, given that privacy law is already premised on the idea that telling the truth in certain situations can be wrong. ${ }^{43}$ In addition, he said that the judgments in Lonrho had been made before MOPI was recognised, and that it would be incorrect to see a conspiracy case as authoritative in the developing area of privacy. ${ }^{44}$

While Mann $\mathbf{J}$ is correct that privacy claims were not in contemplation at the time of Lonrho, with respect, his reasoning does not engage with the crux of that decision. In Lonrho, the core point of principle recognised was that the law only compensates

\footnotetext{
38 Lonrho (n 4) 1496.

39 ibid 1496.

40 ibid 1502.

41 Hannon (n 6) [54] ff.

42 Richard (n 6) [336]-[337].

43 Hannon (n 6) [56].

44 ibid [57]-[60]. See also Richard (n 6) [337].
} 
someone for injuries to their reputation in limited circumstances, and in particular, only when what is said against them is untrue. The fact that MOPI claims render the disclosure of certain true information legally wrongful does not, as Mann J suggested, necessarily undermine what was said in Lonrho. If anything, the decision is directly on point. Although not being explained in this way, what Mann $\mathbf{J}$ really seems to disagree with is the core principle expressed in Lonrho that the law only compensates reputational injury when it results from untrue allegations. That might be so, but it is a claim that requires further substantiation. In other words, Lonrho cannot simply be explained away on the basis that it was a case about conspiracy not privacy, and that privacy law necessarily makes publication of the truth wrongful in some situations.

Turning to the second point, which is the positive claim underlying Mann J's overall conclusion, he sees it as important that part of the function of MOPI is the protection of reputation. He articulated this in Richard in particular, ${ }^{45}$ relying on obiter remarks made to this effect by both the majority ${ }^{46}$ and minority ${ }^{47}$ in the Supreme Court's decision in Khuja $v$ Times Newspapers Ltd. ${ }^{48}$ For Mann J, recognising that reputation is part of the function of both the law of privacy and defamation is 'entirely rational'. ${ }^{49}$ And for him, this position must be reflected at the remedies stage by the ability of courts to award damages for harm to reputation in MOPI cases.

As with the first point about the applicability of Lonrho, Mann J's reasoning regarding the functions of privacy and defamation law reads straightforwardly, but hides something more contested which requires further consideration. It may be correct that defamation and privacy both provide a degree of protection for a claimant's reputation. But what Mann J's decision does not seem to contemplate is that: (1) the sense in which reputation is protected by the two actions is very different; and (2) that this difference might, in turn, materially impact how courts should approach damages. Both these points are addressed in detail in the final two sections of this article.

45 Richard (n 6) [343]-[345].

46 Khuja v Times Newspapers Ltd [2017] UKSC 49, [2019] AC 161 [21], [34](3).

47 ibid [58].

48 Lord Sumption, for instance, writing for the majority, said that: 'The protection of reputation is the primary function of the law of defamation. But although the ambit of the right of privacy is wider, it provides an alternative means of protecting reputation which is available even when the matters published are true.' ibid [21], quoted in Richard (n 6) [343] (emphasis added by Mann J).

49 Richard (n 6) [345]. 


\section{Reputational harm damages should (generally) not be available in MOPI claims: ZXC and Sicri}

ZXC and Sicri, judgments of Nicklin $\mathrm{J}$ and Warby $\mathrm{J}$ (as he then was) respectively, adopt a different position. Reputational harm damages were not awarded in both cases. But again, looking into the precise reasoning is crucial, because the views taken are different and neither judge explicitly disavows what Mann J held in Hannon and Richard.

In $Z X C$, Nicklin $\mathrm{J}$ adopted what can be described as a 'middle ground' approach. As he explained it, damages in MOPI claims cannot ordinarily include a component for reputational harm. ${ }^{50}$ In order for such damages to be awarded, the defendant would have to be given the opportunity to defend as true any statements that give rise to the MOPI claim. ${ }^{51}$ In coming to this conclusion, Nicklin $\mathrm{J}$ acknowledged that reputation is indisputably part of a person's rights under Article 8 of the European Convention on Human Rights, but noted that English law accommodates Article 8 in different, sometimes overlapping ways, including through defamation, MOPI and data protection legislation. ${ }^{52}$ And while truth or falsity is generally irrelevant to a MOPI claim, ${ }^{53}$ it is a fundamental principle of defamation law that damages 'should not be awarded on a false basis: i.e. where the defamatory allegation can be proved to be substantially or partially true'. ${ }^{54}$ As it happened, in $Z X C$, the claimant proceeded on the basis that the court did not need to decide the truth or falsity of the underlying information for the purposes of his MOPI claim. ${ }^{55}$ It followed that the defendant had no opportunity to defend the truth of the information, so the claimant was barred from recovering reputational harm damages.

At first blush, Nicklin J's solution to the reputational harm issue seems to be a neat one. The approach is broadly consistent with what the Court of Appeal said in Lonrho, because Nicklin $\mathrm{J}$ recognises that the law cannot compensate reputational injury resulting from the truth. At the same time, there is an acknowledgment that such damages could sometimes (though perhaps rarely) arise in the privacy context because, in some cases, the information underlying a MOPI claim could be untrue. The difficulty with the approach is revealed when one considers how it would work

\footnotetext{
50 ZXC (n 6) [150(i)].

51 ibid [150(iii)], [151].

52 ibid [149(i)].

53 ibid [149(iii)].

54 ibid [149(iv)].

55 ibid [152].
} 
in practice. On the facts of $Z X C$, the claimant's concession made matters simple because it meant that Nicklin $\mathrm{J}$ did not need to determine whether the relevant information was true. But in other situations, if his approach was adopted, a judge would effectively need to conduct a 'mini trial' in defamation at the damages stage of a MOPI case, applying the complex defamation law principles on truth, a defence which is now statutorily codified in section 2 of the Defamation Act 2013.

In the course of his decision in Sicri, which is probably the most comprehensive judgment dealing with the issue of reputational harm damages to date, Warby $\mathrm{J}$ made a similar point. He emphasised that it would be a cumbersome process to 'import the relevant legal principles' regarding the defence of truth from defamation into MOPI. ${ }^{56}$ Indeed, Warby $\mathrm{J}$ took the point further, and explained that similar reasoning applies with respect to other defences or justifications that might be available to a defendant in a defamation claim, such as reliance on the 'serious' reputational harm threshold in section 1 of the Defamation Act, the public interest defence in section 4 and the unique limitation regime. ${ }^{57}$ Correctly, in my view, he endorsed the assessment of the defendant's counsel Mr Antony White QC that fighting privacy actions as if they were defamation ones was a 'recipe for legal and procedural chaos'. ${ }^{58}$

For Warby $\mathbf{J}$, the conclusion was that a middle ground approach was to be avoided. Damages for reputational injury, as a matter of principle, should not be available in MOPI claims. ${ }^{59}$ Courts, as he saw it, had rightly resisted attempts over a long period of time to prevent the publication of defamatory statements or to recover reputational harm damages in causes of action other than defamation. ${ }^{60}$ In the end, there was a 'good deal to be said today for the principle, identified long ago by the Court of Appeal in Lonrho...that reputational damages are only available in defamation and limited other torts which are premised on the falsity of the information'. ${ }^{61}$

\footnotetext{
56 Sicri (n 6) [156].

57 ibid [159]-[161].

58 ibid [162].

59 ibid [158], [163]. Interestingly (see at [164]), Warby J thought Sicri itself could be decided on a narrower basis that (even if available) it would not be just in the circumstances to award reputational harm damages. This is because proper treatment of the matter would require a conclusion on defamatory meaning, defamatory tendency, defamatory impact, and defences (i.e. essentially a defamation 'mini trial' of the kind he criticised). The submissions of the parties did not equip him to address those points.

60 ibid [157].

61 ibid [158].
} 


\section{The overall tension in the cases}

Pulling together the above cases, there is a clear division in the current High Court authorities. Although Warby $\mathrm{J}$ in Sicri did not regard his position on reputational harm damages as being necessarily irreconcilable with what was said in Richard, ${ }^{62}$ it seems difficult to see Sicri in any other way than being inconsistent with Richard (and Hannon). Mann J saw reputational harm damages as clearly being awardable in MOPI cases while Warby J did not, and the two patently differed on the status of Lonrho. It can also be noted that neither approach adopts the middle ground framework which emerges from Nicklin J's judgment in ZXC.

This being so, the issue of reputational harm damages in MOPI cases seems ripe for consideration by the Court of Appeal, if and when an appropriate case arises. ${ }^{63}$ There are certain matters reflected in the reasoning of all cases which are likely to be uncontested. In particular, there does not appear to be any substantive disagreement that reputation is within the scope of Article 8, and that reputation is an aspect of what privacy law protects. It is also not in dispute that a fundamental principle of defamation law is that damages for reputational harm cannot be awarded on a 'false basis'.

The central difficulty, even though it is not put this way expressly, is that the judges disagree on how to account for defamation law's insistence on falsity when considering reputational impacts in the privacy context. Based on his reasoning, Mann $\mathrm{J}$ did not think the limitations in defamation law are particularly relevant in the MOPI context, so awards reputational harm damages anyway. In ZXC, Nicklin J suggested that defamation principles can be imported into MOPI jurisprudence. And in Sicri Warby $\mathbf{J}$ expressed scepticism, holding that compensation for reputational injury needs to be confined to defamation. However, what none of these judges delved into is the precise sense in which reputation is protected by defamation and privacy law, and how this bears on the damages question. The remaining parts of this article address these matters. First, I will examine the interests which defamation and MOPI protect, which allows us to see the different way reputation features in each. Second, I analyse the interaction between protected interests and available damages.

62 Warby $\mathrm{J}$ thought that Richard was unique because Richard would have had an 'unanswerable claim in libel': Sicri (n 6) [163].

63 As discussed in the final section of this article, ZXC is pending an appeal to the Supreme Court at the time of writing. While the analysis in this paper is relevant to the appeal as explained below, damages are not directly at issue which means an appellate decision in another case will likely be required for the issues raised here to be squarely addressed. 


\section{Defamation and MOPI: The protected interests and the way reputation features in each}

\section{Defamation}

In the introduction above, in the first paragraph, it was noted that protecting reputation is almost universally understood as the purpose of defamation law. As a broad statement, this is accurate, and will certainly not be challenged here. ${ }^{64}$ However, following a wave of careful defamation scholarship in the past 25 years, it is important to recognise that the proposition is a simplification. Properly understood, defamation law protects a particular aspect of a person's reputation; specifically, a person's interest in not having their standing in society tarnished by false allegations.

To see that this is so, it is useful to start by considering what we mean by 'reputation'. The term is not generally taken to be controversial. Indeed, as Descheemaeker points out, ${ }^{65}$ reputation has been defined by various thinkers in broadly synonymous terms as 'the respect or esteem which a person enjoys in society', ${ }^{66}$ 'what people think of him ${ }^{67}$ or the 'good esteem in which others hold us'. ${ }^{68}$ Your reputation, according to this common understanding, belongs to you - like rights with respect to your body, your reputation is personal. ${ }^{69}$ But, as suggested by these definitions and as explained by Arthur Ripstein, there is also an important difference between your reputation and rights to your body; namely that your reputation is necessarily external, residing as it does in the thoughts and perceptions of others. ${ }^{70}$ It is about you being seen well in the eyes of others or the community at large. ${ }^{71}$ Your reputation, as a result, is something that is both personal and external at the same time. When we say that your reputation

64 Lawrence McNamara describes the view that defamation law protects reputation as 'virtually axiomatic in the cases and the literature': McNamara (n 3) 1.

65 Eric Descheemaeker, 'Protecting Reputation: Defamation and Negligence' (2009) 29 Oxford Journal of Legal Studies 603, 609.

66 Reinhard Zimmermann, The Law of Obligations: Roman Foundations of the Civilian Tradition (Oxford University Press 1996) 1062.

67 Tony Weir, An Introduction to Tort Law (2nd ed, Oxford University Press 2006) 175.

68 Hugo Grotius, The Jurisprudence of Holland (translation RW Lee, Clarendon Press 1926) 481.

69 Arthur Ripstein, Private Wrongs (Harvard University Press 2016) 198.

70 ibid. See also Eric Barendt, 'What Is the Point of Libel Law?' (1999) 52 Current Legal Problems 110, 115.

71 This notion of reputation is also clearly accepted in the case law. See e.g. Plato Films Ltd v Speidel [1961] AC 1090, 1138 (Lord Denning); Berkoff v Burchill [1996] 4 All ER 1008, 1018 (Neill LJ). 
is injured or harmed, this is something that happens to you, but only because of the lesser way in which you are or will be thought of in the eyes of others.

The issue with the basic statement that defamation protects reputation is not, therefore, that we lack an understanding of what reputation is. The difficulty is that, even on a cursory examination of the features of defamation law, reputation is far too broad a concept to describe the interest underlying the tort. Taking other torts actionable per se as a point of contrast, the concept of bodily integrity is tightly knit together with the tort of battery; similarly, one's interest in land matches what is protected by the tort of trespass to land. As is firmly established at common law, even the slightest interference with body or land in these cases can be sufficient to impose liability. ${ }^{72}$ The relationship between reputation and defamation is clearly not like this. Despite being actionable per se, the mere fact that someone's actions or words lower your standing in the eyes of others is not sufficient for liability. Defamation can only be committed when what is published lowers the claimant's social standing and where what is said about them is false. ${ }^{73}$ That imputations must be false is not a secondary or ancillary aspect of the action. Falsity is essential to the way the tort operates. ${ }^{74}$

For this reason, a better way of understanding defamation law is that it protects someone's interest in not being judged by society on the basis of false facts. This point, or a variation of it, has now been made by several authors. Thomas Gibbons, for example, argues that it is misleading to speak of the law of defamation as vindicating a right to reputation, and moreover, that it would not be appropriate for an individual to decide the assessment of their reputations. ${ }^{75}$ What is reasonable, however, is for an individual to 'expect that social judgments are based on an adequate

72 As regards battery, Robert Goff LJ in Collins $v$ Wilcock [1984] 1 WLR 1172, 1177 said: 'The fundamental principle, plain and incontestable, is that every person's body is inviolate. It has long been established that any touching of another person, however slight, may amount to a battery'. Similarly, in trespass to land, even placing one's foot into the boundary of someone's land can be sufficient. As Lord Coleridge said in Ellis v Loftus Iron Co (1874) LR 10 CP 10, 12, 'if the defendant place a part of his foot on the plaintiff's land unlawfully, it is in law as much a trespass as if he had walked half a mile on it.'

73 As noted above, the truth defence (previously known as justification) is now codified in the Defamation Act, 2. According to s 2(1), if the imputation conveyed by the statement complained of is 'substantially true' this is a complete defence.

74 This is not meant to imply that substantive defamation law is concerned solely with falsity. There are a number of other defences in defamation law which the defendant can rely on even if the information is false e.g. the public interest defence and honest opinion. The claim is that a person's interest in not being judged on the basis of false facts is, at its core, the interest the defamation action protects.

75 Thomas Gibbons, 'Defamation Reconsidered' (1996) 16 Oxford Journal of Legal Studies 587, 593. 
factual foundation'. ${ }^{76}$ In his detailed study of private wrongs, Ripstein argues that features of defamation law which prima facie appear confusing become transparent when your right against defamation is understood as 'an instance of your basic right to have no wrong attributed to you that you did not do' ${ }^{77}$ The procedural structure of defamation, for Ripstein, 'follows from the fact that only your deeds can determine your standing in the eyes of the community'. ${ }^{78}$ And in his insightful historical analysis of the truth defence, Descheemaeker argues that English law's long-standing adherence to the principle veritas non est defamatio ('truth is no defamation') becomes an 'axiomatic truth' ${ }^{79}$ if it is accepted that defamation protects reputation, but that reputation is an 'ellipsis for deserved reputation' ${ }^{80}$ Defamation, on this view, does not protect a stained character. Rather it protects someone against stains which are undeservedly cast on an individual by someone else.

There is one further point to be noted before turning to MOPI. When it is said that the protected interest of defamation law is a specific aspect of a person's reputation, this is not meant to imply that this is the only thing valuable to us which defamation law can conceivably protect. Indeed, there may be a variety of aspects of one's well-being, such as the ability to form relationships with others, holding down a job, wealth, or mental stability which are protected or fostered in certain situations as a result of our social standing being secure against false allegations. The crucial point to note, however, is that these other goods (and it is impossible to come up with a definitive list) are protected incidentally or parasitically. ${ }^{81}$ Such goods are in no way the primary focus of defamation law, but defamation law might provide a basis for keeping these other goods secure in some circumstances. There is no widely recognised legal shorthand to describe this distinction. For simplicity, the relevant aspect of reputation

76 ibid 593. See also Andrew Kenyon, 'Defamation, Privacy and Aspects of Reputation' (2019) 56 Osgoode Hall Law Journal 59, 73-74.

77 Ripstein (n 69) 192. Ripstein, it should be noted, rejects an important aspect the methodological approach presupposed in this paper; namely, that the tort of defamation is concerned with the protection of an interest which is intelligible outside the mode of its protection. For Ripstein, the right that gives rise to an action in defamation is a right that can only be understood in relation to the possibility of legal proceedings (see 193-198). While I disagree with Ripstein on this methodological point, this idea is not unpacked further in this article. For present purposes, the key is simply that Ripstein (like other authors) does not see defamation as protecting some general concept of reputation.

78 ibid. See also Rowbottom (n 5) 123.

79 Eric Descheemaeker, "Veritas Non Est Defamatio"? Truth as a Defence in the Law of Defamation' (2011) 31 Legal Studies 1, 19.

80 ibid 16 (emphasis added).

81 Descheemaeker makes a related point describing the protection of interests other than reputation in defamation law as 'parasitic': Descheemaeker, 'Protecting Reputation' (n 65) 615-616. 
identified above will be referred to as the 'core' interest protected by defamation law, distinct from 'subsidiary' interests which are protected incidentally.

\section{MOPI}

The core interest protected by the misuse of private information tort, as its name suggests, is 'informational privacy'. ${ }^{82}$ This is also something that we know from the way that the tort was developed, given that English law's long-standing lacuna in privacy protection was front-and-centre when the action was initially formulated. In Campbell v MGN, the seminal decision in MOPI's initial development, Lord Nicholls explicitly stated: 'this tort, however labelled, affords respect for one aspect of an individual's privacy. That is the value underlying this cause of action' ${ }^{83}$ By using the language 'one aspect', Lord Nicholls made it clear that the new action based on information does not necessarily extend to the whole of individual privacy. And this is subsequently confirmed when he went on to specify that strip-searches were an example of a privacy invasion not involving information publication. ${ }^{84}$

Compared with reputation, one of the difficulties with privacy is that it is a much more contested concept, which is the subject of constant theoretical debate. That makes the scope of 'informational privacy' difficult to pin down. Nonetheless, it is suggested that a good working conception of informational privacy, which is consistent with the broad development of the MOPI action, is that it describes an individual's control over the use of information about themselves. ${ }^{85}$ 'Information', as has already been alluded to above, is a broad concept itself not capable of precise definition. The important point for present purposes, however, is that the concept is sufficiently

82 One finds the term 'informational privacy' throughout the theoretical literature on privacy. In the English legal context, see particularly the work of Nicole Moreham: E.g. NA Moreham, 'The Nature of the Privacy Interest' in NA Moreham and others (eds), Tugendhat and Christie: The Law of Privacy and The Media (3rd edn, Oxford University Press 2016) paras 2.10-2.28; NA Moreham, 'Beyond Information: Physical Privacy in English Law' (2014) 73 Cambridge Law Journal 350; NA Moreham, 'Privacy in the Common Law: A Doctrinal and Theoretical Analysis' (2005) 121 Law Quarterly Review 628.

${ }^{83}$ Campbell (n 13) [15].

84 ibid.

85 This conception is similar to the definition proposed by Moreham who defines informational privacy in terms of accessing information about you against your wishes: Moreham, 'The Nature of the Privacy Interest' (n 82) paras 2.11-2.13; Moreham, 'Beyond Information: Physical Privacy in English Law' (n 82) 354. There are, however, slight differences. Although not elaborated upon here, my view is that the language of 'control over use' better encapsulates the interest and what is protected by the MOPI tort than Moreham's notion of 'desired inaccess'. 
capacious that 'false' information about a person can sometimes fall within the scope of informational privacy - while the information concerned is generally true, this is not always the case. ${ }^{86}$

Just like defamation law, the identification of informational privacy as the core interest protected by MOPI does not mean that subsidiary interests are not protected via the tort as well. For those long-accustomed to the deficiencies of English privacy law, this may be somewhat unfamiliar territory - all too often, it is privacy which is the subsidiary interest being incidentally protected by other torts such as trespass to land. But with MOPI, informational privacy is the primary interest protected, and anything else that informational privacy helps secure in a particular case is protected incidentally.

Understood in this way, it becomes clear exactly how MOPI protects reputation. As described above, your reputation (and not just the aspect of reputation protected by defamation) refers to how you are seen in the eyes of the community around you. This being so, there is little doubt that violations of your informational privacy could have a resultant impact on your reputation. If someone's control over the use of information about them is compromised, this could clearly result in personal details being released which could in turn impact on how that person is seen in the eyes of others. Moreover, where the information in question is false, what is protected by defamation and MOPI can overlap. To take but one example, publicising incorrect health information about someone (for instance, saying that an individual has transmitted HIV to someone else when they have not) could be an interference with their informational privacy, and be defamatory at the same time. What is absolutely crucial to note, however, is that when looking through the lens of MOPI, any reputational impacts (whether based on true information or not) have an entirely incidental quality.

Acknowledging this difference in the way that reputation features in defamation and MOPI is, with respect, a crucial point missing from the reasoning in the decisions outlined above. When Mann $\mathrm{J}$ in Richard said that the protection of reputation is part of the function of both defamation and privacy, ${ }^{87}$ this is an oversimplification. For one, it is not a person's reputation at large which is the focus of defamation; the core interest protected is a person's specific interest in not having their standing in society tarnished by false allegations. As regards MOPI, a person's reputation (understood

86 This point is reflected in the MOPI case law - see e.g. McKennitt (n 7) [86] (Longmore LJ); ZXC (n 6) [149(iii)].

87 See particularly Richard (n 6) [345]. 
broadly) might be protected, but only incidentally, parasitic on the primary function of the tort.

\section{The interface between protected interests and damages}

Understanding the interests protected by defamation and MOPI is an important step in determining whether damages for reputational harm should be available in privacy claims. But there is still one piece left in the puzzle. To complete the task, we need to be clear on how the interests protected by MOPI interact with the damages which are available.

\section{Core interests and interference damages}

To start with, it is helpful to be clear on terminology. In the preceding section, it was pointed out that contemporary remedies scholarship does not seem to have a wellestablished nomenclature to distinguish between what have been termed the 'core' and 'subsidiary' interests protected by a tort. When it comes to damages, however, the position is better-developed so far as labels are concerned. Where a tort has been committed, at least some of the subsidiary interests protected by the tort line up with what is typically regarded as the claimant's 'consequential loss' ${ }^{88}$ These are the particular or actual consequences which the claimant has suffered such as economic loss or distress which flow from the defendant's wrongful act. ${ }^{89}$ By contrast, the damages which are awarded for interference with the core interest a tort protects align with what some scholars call the "normal loss' ${ }^{90}$ or 'pure loss'. ${ }^{91}$ These terms are not used here because it is not necessary for present purposes to determine whether, or in what sense, interference with a core interest represents a 'loss' to the claimant. ${ }^{92}$

88 See Descheemaeker, 'Protecting Reputation' (n 65) 615-616.

89 ibid 614; Edelman (n 2) para 3-008.

90 Edelman (n 2) para 3-008. This paragraph cites Admiralty Commissioners $v$ SS Susquehanna [1926] AC 655, 661 where Lord Denedin distinguished between damages which 'give the injured party reparation for the wrongful act...' and damages which are given for 'all the natural and direct consequences of the wrongful act'.

91 Descheemaeker, 'Protecting Reputation' (n 65) 612-613.

92 Some scholars, such as Robert Stevens, do not see damages awarded for the infringement of a right as compensating for a loss: Robert Stevens, Torts and Rights (Oxford University Press 2007) 59-62. He uses the term 'substitutive damages'. That term is not used here, because it is not necessary in this context to conclude whether such damages are compensatory or substitutive. 
Therefore, I will simply describe damages awarded for interference with the core interest which a tort protects as 'interference damages'. 93

Courts in both MOPI and defamation cases appear to have accepted that substantial interference damages can be awarded for each tort. ${ }^{94}$ For MOPI, interference damages are damages for the loss of control of information. In MOPI jurisprudence, these have been explicitly framed as damages for infringement of the right which MOPI protects, as distinct from damages for pecuniary losses or distress. ${ }^{95}$ Defamation law, it can be observed, has long awarded interference damages as well, in the form of damages for reputational harm. ${ }^{96}$ Such damages correspond directly to the core interest that defamation law seeks to protect. And they too can be understood as being analytically separate from damages for pecuniary losses or the negative emotions a claimant suffers following a defamatory statement. ${ }^{97}$

The crucial point about interference damages is that they are specific to individual torts. In MOPI cases, interference damages are loss of control damages; in defamation, interference damages are damages for reputational harm. Any damages awarded for anything other than interference with the core interest a tort protects are not interference damages. Thus, courts may compensate for the pecuniary loss or distress

93 Those familiar with recent MOPI scholarship may wonder whether by interference damages I am referring to what others, such as Varuhas and Descheemaeker, have called damages for a 'normative loss', as distinguished from 'factual losses'. That terminology is avoided here because it is not clear to me that there is a meaningful conceptual distinction to be drawn between losses suffered in the 'real world' (factual losses), as opposed to losses associated with the infringement of a right which do not occur in the 'real world' and are legally constructed (normative losses). As noted above, our right to reputation (understood in a broad sense) is both personal and external at the same time it is an individual right that only makes sense by reference to observable effects. As such, injury to reputation does not seem to fall neatly along so-called factual/normative lines.

94 This article is confined to MOPI and defamation and so no general theory is advanced in detail here about which torts give rise to interference damages and which do not. It is suggested, however, that interference damages will be available for torts 'involving strict liability for deliberate acts', rather than torts 'based on a want of care'. This is the distinction drawn by Lord Leggatt in the Supreme Court's recent decision in Lloyd (n 28) [133], when identifying the torts for which damages may be awarded 'without proof of material damage or distress'.

95 See the discussion at the end of the first section above, with references to the relevant portions of Gulati $v M G N$ (at first instance and appeal) at text accompanying footnotes 23 and 24.

96 See Descheemaeker, 'Protecting Reputation' (n 65) 611-613, quoting from McCarey $v$ Associated Newspapers Ltd [1965] 2 QB 86, 107-108 (Diplock LJ). As Descheemaeker notes, damages for injury to reputation can be understood as damages for the infringement of the claimant's reputation, in and by itself.

97 Descheemaeker, 'Protecting Reputation' (n 65) 612. 
suffered by a claimant as a result of a MOPI or defamation claim. But money or mental health is not the core interest protected by MOPI, defamation or indeed any other tort. Indeed, this explains why consequential losses (e.g., for pecuniary loss or distress) are recoverable for a variety of torts. These awards are not specifically awarded for interference with the core interest protected by any tort and, as such, no one tort has a monopoly on them.

\section{Application of these concepts}

Adopting this terminology, we can unpack what is happening when courts (as in Richard) award reputational harm damages in MOPI cases. Reputation is not a core interest protected by MOPI; it is only ever protected in an incidental way. But reputation is also different from other subsidiary interests like wealth or mental wellbeing which correspond with consequential losses the law compensates when they flow from the defendant's wrongful act (e.g. via damages for pecuniary losses or distress). This is because the law has carefully chosen to protect a specific aspect of reputation as the core interest of another tort, defamation, and award reputational harm damages as the interference damages for that tort. The specific jump that is made in Mann J's reasoning is his acceptance that the interference damages corresponding to both the MOPI and defamation torts can be awarded in a MOPI claim.

This approach, it is suggested, is patently undesirable. No matter what one thinks about courts awarding interference damages in MOPI cases, taking the further step of additionally awarding the interference damages for defamation is unsound as a matter of principle. The obvious difficulty is that it runs roughshod over the careful and limited way in which the law has chosen to protect reputation. As detailed above, the core interest protected by the tort of defamation is not reputation in a general sense. Rather, over time, lawmakers have crafted an action which protects a person's specific interest in not being judged by society on the basis of false facts. Damages for reputational harm awarded in defamation cases line up perfectly with this interest. They are interference damages, awarded for interference with the core interest protected by the tort, only in circumstances where the precise conditions for liability are met and where no defences (including truth) are available. To transfer reputational harm damages into the MOPI context is to allow for the direct circumvention of these precise conditions.

To be clear, the point being made here is not that the same set of facts cannot give rise to a successful claim for loss of control damages as well as reputational harm damages. Rather, the key is that these are a very particular species of damages which are connected to the core interests protected by individual torts. In order for both sets of damages to be available, both torts need to be pleaded and proved. This, of course, 
may be precisely what the claimant should have done in Richard. As noted above, Warby $\mathbf{J}$ in Sicri justified the result in that case on the basis that Richard had an 'unanswerable' claim in defamation. ${ }^{98}$ But properly understood, if the defamation and MOPI cases were both valid, both should have been proved according to the conditions for liability laid down for each tort.

Although the point is not mentioned in either Richard or Sicri, it is worth thinking about why Richard, well advised as he was, chose not to pursue a defamation claim even though he supposedly had an 'unanswerable' case. The most plausible answer seems to relate to timing and the strict one-year limitation period for defamation. ${ }^{99}$ Strategically, it would have been disastrous for Richard to bring a defamation claim within a year of the BBC's coverage because the investigation remained on foot at this time and the BBC might have sought to run a truth defence. ${ }^{100}$ By allowing reputational harm damages to be recovered through MOPI (which could be pleaded once the investigation had concluded given its longer limitation period), Mann $\mathbf{J}$ effectively permitted the claimant to circumvent defamation's strict limitation requirement.

Understanding these practical differences between MOPI and defamation is important because it also explains the difficulty with the middle ground approach reflected in the reasoning of Nicklin $\mathrm{J}$ in $Z X C$. At its face this strategy seems appealing because it acknowledges that reputational harm damages cannot be awarded where what is said about the claimant is true. However, as has been alluded to above, the only way of ensuring that the truth defence and other defamation issues are dealt with properly is effectively to conduct a 'mini trial' in defamation at the damages stage of a MOPI case. Thinking about limitation periods reveal that even this approach would be fraught with problems - it is difficult to see how the different limitation period for defamation which has specifically been adopted by Parliament could ever be accounted for within a MOPI claim. A much more satisfactory position is for defamation to be separately pleaded if available, alongside the MOPI tort.

98 Sicri (n 6) [163]. See footnote 62 above, and text thereto.

99 The limitation period for defamation was previously the same as other torts i.e. six years from the date of accrual of the cause of action. The rationale for the reductions was the view that a person whose reputation has been harmed should pursue their claim vigorously: Austin v Newcastle Chronicle \& Journal Ltd [2001] EWCA Civ 834 [38]; Mullis and Parkes (n 1) para 19.13.

100 The BBC coverage of the police investigation into Richard was in August 2014, but he remained under investigation until June 2016 when it was announced that no charges would be brought against him: Richard (n 6) [2]. 
Taking such an approach, it should be noted, is consistent with the way individual causes of action are generally differentiated throughout the English legal system, and particularly in tort law. If someone walks onto my land without permission and hits me, we might conveniently describe this as one set of 'facts'. In my claim form, however, I will plead two causes of action because there are two legally recognised wrongs which have occurred: trespass to land and battery. If I meet the requirements which lawmakers have laid down for each tort, I can potentially recover damages for both. Similarly, if someone publishes an article which makes defamatory claims about me as well as disclosing private information, there are two legal wrongs occurring here not one. And I am entitled to damages for both, but only if I can prove both. ${ }^{101}$

\section{Additional advantages of the interference damages approach}

Having the language of core interests and interference damages allows us to see the doubling up which is occurring in Mann J's reasoning in Richard in a particularly salient way. But the approach has at least three other advantages as well.

The first is that it sheds light on why the central principle originally expressed in Lonrho was correct, and why Warby J was right to endorse it years later in Sicri. If anything, it can now be appreciated that the principle could have been framed in even stronger terms. In Lonrho, as noted briefly above, the Court of Appeal unanimously held that, as a general rule, damages for injury to reputation could only be recovered in an action for defamation. Both Dillon LJ and Stuart-Smith LJ, however, acknowledged that this principle is subject to exceptions. ${ }^{102}$ Stuart-Smith LJ pointed to occasional historical awards of reputational damages in false imprisonment and malicious prosecution cases as examples. ${ }^{103} \mathrm{He}$ saw these awards as justified on the basis that the defendant's wrongful act casts an imputation on the reputation of the claimant even though no defamation claim is available (because, for instance, false imprisonment does not involve the making of a statement). When Warby $\mathrm{J}$ endorsed Lonrho in Sicri, he similarly seemed to acknowledge the possibility of exceptions,

\footnotetext{
${ }^{101}$ As this paper is squarely focussed on the availability of reputational harm damages, the issue of whether, or in what circumstances, it is an abuse of process to bring a privacy claim to circumvent the rules of defamation has not been addressed. As reflected throughout this paper, however, there may be various situations where defamation and MOPI overlap. Where there is an overlap, there seems to be no principled reason why the claimant should not be permitted to plead either or both.

${ }^{102}$ Lonrho (n 4) 1496 (Dillon LJ), 1504 (Stuart-Smith LJ).

103 ibid 1504.
} 
holding that 'reputational damages are only available in defamation and limited other torts which are premised on the falsity of the information'. ${ }^{104}$

Once we understand that reputational harm damages are interference damages for the tort of defamation, we can see that these qualifications could lead to confusion. Properly understood, the reputational harm damages which are awarded in defamation cases are unique to the tort, because they correspond to interference with the core interest which the tort protects. It is not useful to think about this conclusion as one which is subject to exceptions in certain cases. Doing so makes us lose sight of the precise way reputational harm damages are tethered to the core interest which the tort of defamation protects.

A second benefit of adopting the framework above is that it helps maintain the boundary between defamation and MOPI, while acknowledging that there may often be circumstances where the privacy tort is residually protecting a claimant's reputation. In $Z X C$, which at the time of writing is pending an appeal to the Supreme Court, the availability of damages for reputational harm is not directly at issue. The primary question on appeal is whether, and to what extent, a person who has not been charged with an offence can have a reasonable expectation of privacy in relation to information that relates to a criminal investigation into their activities. ${ }^{105}$ In commentary on the Court of Appeal's determination that a person generally does have a reasonable expectation of privacy in such circumstances, it has been argued that the decision results in MOPI straying into territory traditionally covered by defamation law. ${ }^{106}$ From a practical perspective, if courts take the position that reputational harm damages can be recovered in a MOPI case, then this concern is a very real one.

If, however, it is acknowledged that reputational harm damages are interference damages tied to defamation, much of this concern about privacy and defamation law blurring together can arguably be alleviated. The approach defended in this article allows the court to maintain the position that a person can generally have a reasonable expectation of privacy in a police investigation concerning them (or other matters significantly impacting their reputation), without having to accept that this necessarily conflates defamation and privacy. This is because reputational harm cannot directly be compensated via MOPI.

\footnotetext{
${ }^{104}$ Sicri (n 6) [158] (emphasis added).

105 This is the first controversial background issue which was canvassed above in the first section of this article.

${ }^{106}$ Moreham, 'Privacy and Police Investigations' (n 5) 6-7.
} 
The third benefit of the above approach is that it helps sharpen our understanding of MOPI interference damages i.e. damages for loss of control of information. As these damages are still in their infancy, courts have still not had to grapple with the range of difficult issues which might arise about their availability. However, some of those questions are starting to emerge. In Lloyd v Google, for example, the Supreme Court recently held that damages for loss of control of information were not available in a claim for compensation under the DPA. ${ }^{107}$ Although a detailed discussion of Lloyd and data protection legislation is beyond the scope of this article, ${ }^{108}$ it is worth noting that Lord Leggatt's analysis is consistent with the argument above. In particular, one of the important reasons for not reading across the damages approach from MOPI to the DPA context was that information is only protected in MOPI where there is a reasonable expectation of privacy, whereas there is no such requirement in the DPA context. ${ }^{109}$ This supports the claim that loss of control damages should be tethered to MOPI - holding otherwise would allow circumvention of the precise way in which English tort law has chosen to protect an individual's informational privacy.

Looking more widely beyond data protection, it can also be said that loss of control damages should not be awarded in torts which protect different core interests. Drawing an analogy from Mann J's reasoning in Richard, it is not inconceivable that a claimant would seek to recover loss of control damages in novel situations like a false imprisonment or trespass to land claim if the defendant acquired private information about the claimant in the process. Based on the approach adopted above, it can be appreciated that there is a clear, principled reason why loss of control damages should not be awarded in these circumstances. Such damages are interference damages, and can only be awarded if the claimant pleads and proves MOPI in addition to trespass or false imprisonment.

\section{Conclusion}

This article has sought to make a relatively narrow but important claim, arguing that damages for reputational harm which have long been awarded in defamation law should not be available in MOPI claims. Although this aligns with the conclusion in the most recent High Court case on the issue, Sicri, different positions are espoused in the judgments of Hannon, Richard and $Z X C$, making this a live issue ripe for consideration by the Court of Appeal.

\footnotetext{
${ }^{107}$ See particularly Lloyd (n 28) [105]-[138].

${ }^{108}$ See footnotes 28 and 29 above.

${ }^{109}$ Lloyd (n 28) [130]-[131].
} 
If and when the issue does arise for resolution in another case, there are two key propositions which should be borne in mind which can help clarify matters. The first is that the core interest protected in defamation and MOPI cases is very different. In defamation, the core interest protected is not reputation generally but rather a person's specific interest in not having their standing in society besmirched by false allegations. For MOPI, the core interest protected is informational privacy; reputation is only ever protected in an incidental way. The second proposition is that reputational harm damages are a particular species of damages, which I have called interference damages, awarded for interference with the core interest protected by a tort. Adopting this language allows us to see clearly that awards of reputational harm damages in MOPI claims represent interference damages for two different torts being made in the same claim. This is clearly undesirable, most importantly because it allows circumvention of the careful and limited way in which the law has chosen to protect reputation.

\section{Acknowledgements:}

A version of this article was presented in the Media and Communications Law section of the 2021 SLS Annual Conference at the University of Durham. I am grateful to the participants for their perceptive comments. I would also like to thank my research supervisors George Letsas and Paul Mitchell who provided detailed feedback on earlier drafts. Finally, for numerous constructive comments and helpful suggestions, thanks to Matthew Barry, Aarushi Sahore and the anonymous reviewer at the Journal of Media Law.

\section{Notes on author:}

Jeevan Hariharan is a PhD Candidate and Associate Lecturer at the Faculty of Laws, University College London. He holds BA (First Class) and LLB degrees from the University of Sydney, where he was awarded the University Medal in Philosophy, as well as an LLM (First Class) from the University of Cambridge, where he received the Lucas-Smith Memorial Prize for the top law student at Queens' College. 